\title{
Doświadczenia konsumenta podczas zakupu prezerwatyw - analiza emocji i ścieżki klienta
}

\section{Wstyd}

Wstyd należy do emocji samoświadomościowych, czyli pojawiających się w życiu jednostki stosunkowo późno i angażujących złożone mechanizmy psychologiczne. Występuje w obliczu dylematów moralnych, w których zazwyczaj uczestniczy widownia. Oznacza to, że uruchamia się najczęściej w sytuacji społecznej (na przykład gdy ktoś na nas patrzy) lub gdy uwaga zostanie skierowana na „Ja” (gdy ktoś zadaje pytania dotyczące naszej osoby). Skutkiem jest ocena własnego zachowania i porównania go z wewnętrznymi wartościami ${ }^{1}$.

Jak większość pojęć w naukach humanistycznych wstyd jest definiowany na więcej niż jeden sposób. Erving Goffman w swoich pracach wielokrotnie poruszał wątek zażenowania, uznawanego za jeden z rodzajów wstydu. Pisał o twarzy, jednak nie w kontekście występujących na niej ekspresji mimicznych, lecz w ujęciu metaforycznym. Uważał, że twarz jest czymś, co można zachować lub utracić. Utrata twarzy następuje, gdy obraz własnego „Ja” jednostki nie jest spójny z oceną innych osób. Zażenowaniem zajmował się również Paul Ekman, który określił je jako specyficzną kombinację nieśmiałości i poczucia winy następującą w wyniku uruchomienia samoświadomości ${ }^{2}$.

1 A. Młynarska-Jurczuk, Wstyd jako emocja ucieleśniona - twarz, ciało i role płciowe $w$ procesie społecznej konstrukcji wstydu, „Dyskursy Młodych Andragogów” 2016, nr 17, s. 357.

${ }^{2}$ K. Konecki, Socjologia emocji wedtug Thomasa Scheffa, [w:] Emocje w życiu codziennym. Analiza kulturowych, społecznych i organizacyjnych uwarunkowań ujawniania i kierowania emocjami, red. K. Konecki, B. Pawłowska, Łódź 2014, s. 17-19. 
Charles H. Cooley swoją definicję wstydu oparł na koncepcji jaźni odzwierciedlonej (ang. looking glass self). Oznacza ona nieustanne monitorowanie i modyfikowanie swojego zachowania spowodowane obecnością innych. Na samo pojęcie jaźni składają się trzy komponenty: wyobrażenie sobie, jak jesteśmy postrzegani przez inną osobę, wyobrażenie sobie dokonanej przez nią oceny, a także komplementarnej emocji wywołanej tą oceną, na przykład wstydu, dumy czy upokorzenia ${ }^{3}$.

Wstyd może również wystąpić bez obecności widowni. Pojawia się, gdy jednostka nie realizuje zadań związanych z osiąganiem narzuconego sobie celu lub postępuje niemoralnie odnośnie do przyjętych norm społecznych ${ }^{4}$. Aspekt samotnego doświadczania staje się jednak nieistotny w obliczu przyjętego przeze mnie scenariusza, jakim jest robienie zakupów.

\subsection{Wpływ wstydu na zachowania konsumenckie}

Odwracanie wzroku i twarzy, chęć schronienia się, a nawet ucieczki są charakterystyczne dla doświadczania wstydu - są to uniwersalne reakcje fizjologiczne towarzyszące tej emocji ${ }^{5}$. Istotne jest jednak, jak może ona wpłynąć na zachowania konsumentów. Znalezienie się we wstydliwej sytuacji w sklepie może powodować wiele mechanizmów obronnych.

Pierwszym z nich jest rezygnacja z zakupu wybranego produktu (ang. abandoning

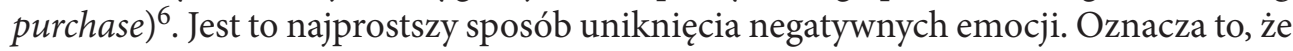
komfort psychiczny i zachowanie dobrego wizerunku własnej osoby są ważniejsze od pozyskania niektórych towarów.

Kolejną metodą jest opóźnianie zakupu (ang. delaying purchase) ${ }^{7}$. Jest ona stosowana, gdy produkt okazuje się niezbędny, więc uniknięcie nieprzyjemnego doświadczenia związanego $\mathrm{z}$ jego zakupem nie jest możliwe. Strategia ta polega na opóźnianiu samego procesu, na przykład przez robienie zakupów w mniej popularnych godzinach, unikanie kontaktu z obsługą czy czekanie, aż większość klientów opuści sklep.

Następną strategią jest dodatkowy zakup (ang. additional purchase) ${ }^{8}$. Gdy osoba kupuje produkt uznawany za wstydliwy, często stara się ukryć prawdziwy cel swoich zakupów, dodając do koszyka produkty neutralne lub przynajmniej takie, które nie wywołują zażenowania, co ma zapobiegać wystąpieniu niepożądanego wizerunku powstającego podczas zakupów.

\footnotetext{
${ }^{3}$ Ibidem, s. 16-19.

${ }^{4}$ Y.T. Li, D.F. Yang, H. Zhou, A literature review of consumption embarrassment and prospects, „American Journal of Industrial and Business Management” 8, 2018, s. 688-690.

5 A. Młynarska-Jurczuk, op. cit., s. 358-363.

6 Y.T. Li, D.F. Yang, H. Zhou, op. cit., s. 694-695.

7 Ibidem, s. 694.

8 Ibidem.
} 
Ostatnim mechanizmem są zakupy kompensacyjne (ang. compensation purchase $)^{9}$. Osoby, które odczuwają wstyd, są zmotywowane do tego, żeby odbudować swój uszkodzony wizerunek. Jednym ze sposobów jest zakup produktów wysoce związanych z atrakcyjnością. Jest to symboliczna strategia radzenia sobie, więc produktami kompensacyjnymi mającymi służyć naprawieniu „utraconej twarzy” są najczęściej kosmetyki.

\section{Zakup prezerwatyw}

Zakup prezerwatyw często wywołuje poczucie wstydu, którego źródłem może być sama specyfika produktu - konotacje z nim związane i oczywiste przeznaczenie. Zdaje się jednak, że problemem nie jest kupno drobnego kolorowego pudełeczka, lecz publiczność obserwująca proces. Skoro zawartość pudełka ma tylko jedno zastosowanie, to zdjęcie go z półki staje się niezwerbalizowaną deklaracją nadchodzącego stosunku seksualnego. Wstyd jest spowodowany zaproszeniem publiczności sklepowej do prywatnego świata, do swojej sfery intymnej.

W celu prześledzenia doświadczenia krok po kroku przedstawię je za pomocą ścieżki klienta. Podstawą opisu procesu są dwa badania polegające na analizie narracji konsumentów. Autorkami pierwszego z nich są Kristin Joos i Leslie H. Picca. Drugie badanie zostało przeprowadzone przeze mnie i jest replikacją oryginału. Uznałam, że skoro nie ma polskich publikacji na ten temat lub tematy pokrewne, to warto sprawdzić, czy doświadczenia konsumentów różnią się kulturowo.

\subsection{Metodologia badań}

Badanie $\mathrm{z}$ The great condom adventure: Analyzing college students' narratives of buying condoms zostało przeprowadzone w 2009 roku na grupie studentów z University of Dayton. Jedna $\mathrm{z}$ autorek artykułu jest tam wykładowczynią i w ramach kursu z nauk społecznych poprosiła swoich uczniów o wykonanie dodatkowego zadania. Mieli udać się do dowolnego sklepu i kupić prezerwatywy, a następnie opisać swoje doświadczenia. Każdy ze 115 ochotników został poinformowany o tym, że jego wypowiedź stanie się częścią badania ${ }^{10}$.

Próbą badawczą w replice eksperymentu była grupa 20 studentów Uniwersytetu Wrocławskiego w wieku od 20 do 24 lat. Uczestnicy wypełnili internetowy formularz udostępniony w sierpniu 2020 roku na facebookowej grupie Uniwersytet Wrocławski Studenci. W skład kwestionariusza wchodziła metryczka, w której znalazły się pyta-

9 Ibidem, s. 695.

10 K. Joos, L.H. Picca, The great condom adventure: Analyzing college students' narratives of buying condoms, „Sociology, Anthropology, and Social Work Faculty Publications” 8, 2009, s. 4-5. 
nia o wiek i płeć, a także część badawcza z prośbą o przypomnienie sobie i opisanie ostatniego doświadczenia z zakupem prezerwatyw. Badani zostali poinformowani, że ich odpowiedzi będą częścią artykułu.

Opisy badanych przyporządkowałam do poszczególnych etapów ścieżki konsumenta pojawiających się $\mathrm{w}$ publikacji The great condom adventure...: planowanie, wejście do sklepu, szukanie i wybór produktu, transport do kasy, wybór kasjera i zakup, oczekiwanie na reakcję oraz refleksje. Badani nie byli świadomi wybranej przeze mnie formy kategoryzacji ich odpowiedzi. Przedstawienie jej mogłoby wpłynąć na ich opisy, sugerując schemat, do którego muszą się dopasować. Co więcej, pominięcie $\mathrm{w}$ wypowiedzi któregoś z przyjętych przeze mnie etapów jest diagnostyczne samo w sobie - świadczy o różnicy w narracji między studentami amerykańskimi a polskimi.

Znaczącym ograniczeniem obu badań jest stosunkowo mała próba, więc jakiekolwiek wynikające $\mathrm{z}$ nich wnioski nie mogą być reprezentatywne dla osób w przedziale wiekowym 20-25 lat, a nawet dla wszystkich studentów. Dodatkowo należy uwzględnić, że udział w obu badaniach był dobrowolny, więc nie wiemy, co kierowało uczniami, którzy zdecydowali się w nich uczestniczyć (na przykład istotne różnice indywidualne). Ponadto mankamentem polskiego badania jest to, że jego uczestnicy opisywali swoje doświadczenia po czasie - zostali poproszeni o przypomnienie sobie i przedstawienie swojego ostatniego zakupu. W 70\% przypadków okres między zakupem prezerwatyw a badaniem był krótszy niż miesiąc. Skutkiem mogą być mniej szczegółowe wypowiedzi niż w badaniu amerykańskim. Co prawda w pierwotnym artykule nie było dokładnej informacji, ile czasu upłynęło między zakupem prezerwatyw a opisem, ale nastawienie studentów było też inne. Udali się oni do sklepu ze świadomością, że muszą później przedstawić swoje doświadczenie.

Mimo dostrzegalnych wad metody badania te zapewniają wgląd w doświadczenia związane z kupowaniem prezerwatyw, które często są określane jako stresujące i trudne. Być może pozwolą one zrozumieć, czemu wielu młodych ludzi rezygnuje z zakupu i decyduje się na stosunek bez zabezpieczeń lub jakich taktyk używają, by poradzić sobie z zakupem.

\subsubsection{Planowanie}

Wielu uczestników pierwotnego badania zwlekało z wykonaniem zadania i spędziło dużo czasu na planowaniu zakupu. Zastanawiali się, jaki sklep wybrać oraz w jakich godzinach się tam udać. Oznacza to, że przejawiali zachowania związane z opóźnieniem zakupu. Część badanych rozważała zabranie z sobą znajomej osoby, która zapewniłaby im względne poczucie komfortu. Interesujące, że tą osobą nie mógł być partner, z którym planowali wykorzystać produkt: „My boyfriend waited in the car because we were both feeling too shy to go in together. We were worried about what 
the little old lady at the cash register would think of us if she saw us both together purchasing a package of condoms"11.

Uczestnicy polskiego badania nie zwlekali z zakupem ani go nie planowali, co może wynikać $\mathrm{z}$ tego, że ich motywacje różniły się od motywacji pierwszej grupy była to rzeczywista potrzeba nabycia produktu, traktowana jako zwyczajna czynność, a nie zadanie do wykonania: „Byłam tam na zakupach więc przy okazji zakupiłam prezerwatywy” ${ }^{2}$, „Przypomniało nam się podczas zakupów, że nie mamy prezerwatyw, więc uznaliśmy, że trzeba je kupić". Ponadto badani z tej grupy nie doświadczyli dyskomfortu, zabierając swojego partnera na zakupy: „Byłam z chłopakiem w markecie Mila”, ani nie mieli problemu z dyskusją podczas wyboru „Po krótkim sporze, które wybrać".

\subsubsection{Wejście do sklepu}

Mimo wystąpienia etapu planowania część amerykańskich studentów wciąż odczuwała potrzebę prokrastynacji. Objawiało się to na przykład niechęcią do przekroczenia progu sklepu lub fizjologicznymi manifestacjami (drętwienie nóg). Wspomniane reakcje prawdopodobnie nie pojawiłyby się, gdyby studenci zostali poproszeni o zakup innego produktu, na przykład chusteczek higienicznych czy ciastek.

Tuż po wejściu do sklepu badani odnosili wrażenie, że są obserwowani lub oceniani, przejawiali objawy paranoi. Psychologicznym mechanizmem tłumaczącym to uczucie jest efekt światła rampy (ang. the spotlight effect). Zakłada on, że ludzie przeceniają swoją zauważalność, myślą, że są obserwowani przez wszystkich dookoła. Zazwyczaj towarzyszy to sytuacjom wywołującym zakłopotanie ${ }^{13}$.

Jeden z uczestników zadeklarował, że najbardziej obawiał się oceny ze strony seniorów lub osób w wieku rodziców. Uważał, że będzie ona bardziej krytyczna, więc unikał kontaktu wzrokowego z klientami pasującymi do tego opisu. Strach przed opinią osób starszych może być związany z przekroczeniem pewnego kulturowego tabu. Niewielu nastolatków otwarcie rozmawia z rodzicami na temat seksu, a wiedzę o nim czerpie głównie od swoich rówieśników ${ }^{14}$.

Wrocławscy studenci nie wyróżnili etapu wejścia do sklepu, była to dla nich zwyczajna czynność, do której nie przywiązywali większej wagi: „Weszłam tam w drodze na imprezę żeby kupić piwo, a poza tym wiedziałam [ż]e po imprezie widzę się z chłopakiem i muszę kupić te[ $[\dot{z}]$ prezerwatywy".

11 Ibidem, s. 6.

12 Wszystkie wypowiedzi badanych osób przytaczane są w oryginalnej pisowni.

13 N. Heflick, The spotlight effect. Do as many people notice us as we think?, https://www.psychologytoday.com/us/blog/the-big-questions/201111/the-spotlight-effect (dostęp: 14.05.2020).

14 Raport Grupa Edukatorów Seksualnych Ponton, Skąd wiesz? Jak wygląda edukacja seksualna w polskich domach, http://ponton.org.pl/wp-content/uploads/2018/09/Sk\%C4\%85d-wiesz-RAPORT_ostateczny.pdf (dostęp: 14.05.2020). 


\subsubsection{Szukanie i wybór produktu}

Spora część studentów z University of Dayton miała problem ze znalezieniem produktu, jednak tylko $8 \% \mathrm{z}$ nich czuło się wystarczająco komfortowo, aby poprosić obsługę sklepu o pomoc. Trudności związane z namierzeniem artykułu mogą być skutkiem emocji odczuwanych przez grupę badanych. Istotnym czynnikiem może być też sama lokalizacja.

Prezerwatywy można kupić niemalże wszędzie: w aptekach, w drogeriach czy nawet w sklepach spożywczych, jednak to, że są łatwo dostępne, nie sprawia, że łatwo je znaleźć: „Nie byliśmy wcześniej w tym sklepie, więc chwilę nam zajęło ich znalezienie". W typowej drogerii są ukryte między licznymi alejkami obok produktów, które wcale nie muszą się kojarzyć z akcesoriami intymnymi. Oznacza to, że chcąc je kupić, można obejść sklep kilkukrotnie. W sieciach spożywczych, na przykład w Żabce, są zlokalizowane przy kasach. Oczywiście w tym wypadku zarzut o rzekomo kiepskiej widoczności produktu nie jest trafny, za to jego lokalizacja okazuje się dość nieoczywista w związku z tym, że większość artykułów higienicznych znajduje się w innym miejscu.

Przy samym wyborze produktu pojawia się kolejny problem. Istnieje wiele zmiennych różnicujących prezerwatywy: zaczynając od marki czy ceny, kończąc na rozmiarze, smaku czy obecności lubrykantu. Poczucie dyskomfortu i chęć jak najszybszego udania się do kasy sprawiły, że niewielu studentów z obu uniwersytetów zastanawiało się nad wyborem, czytaniem składu, nie wspominając nawet o inicjacji kontaktu z obsługą sklepową celem konsultacji: „Zazwyczaj chodzę obok p[ó]łek i udaje, że niby nie patrz[ę] na prezerwatywy". Mimo że takie pytanie może wydawać się niestosowne, to przecież byłoby zupełnie naturalne podczas zakupu produktów innej kategorii, na przykład balsamu do ciała.

Kolejnym ciekawym spostrzeżeniem jest to, że w przypadku obu badań mniejszy problem $\mathrm{z}$ wyborem prezerwatyw mieli studenci niż studentki. Zapewne jest to związane z utartym kulturowo przekonaniem, że zakup tego produktu jest zadaniem należącym do mężczyzn. Skoro oni noszą prezerwatywy, oni mają je kupować, oni mają coś do powiedzenia w kwestii preferencji: „Ulubione mojego partnera”, „Nie wiem w czym mu najlepiej”. Co więcej, kobiety mające prezerwatywy bywają postrzegane jako „zbyt chętne”, co jest jednym z przejawów podwójnych standardów ${ }^{15}$. To szkodliwe przeświadczenie jest integralnie związane z zespołem Madonny i ladacznicy, który polega na ambiwalentnej postawie mężczyzn wobec kobiecej natury. Może ona przyjmować tylko dwie formy - porządnej, cnotliwej żony i matki lub rozpustnej, namiętnej kochanki ${ }^{16}$. Ten głęboko zakorzeniony stereotyp przekłada się bezpośrednio na doświadczenia konsumentek, skutkując ich niechęcią do dokonania zakupu

15 K. Joos, L.H. Picca, op. cit., s. 3.

16 J. Kotarska, Nie zrobię tego z żona, https://www.psychologiaprzykawie.pl/blog/nie-zrobie-tego-z-zona (dostęp: 14.05.2020). 
lub odczuwaniem negatywnych emocji. Jedna ze studentek z drugiego badania przyznała, że boi się kupna prezerwatyw i zostawia to zadanie swojemu chłopakowi: „Nie chce zostać oceniona przez sprzedawcę, tym bardziej że blisko mnie jest jedna żabka i przy częstszym kupowaniu sprzedawca mógłby mnie zapamiętać”. Natomiast inny student, w którym proces ten nie wzbudził żadnych emocji, dostrzegł specyficzną reakcję swojej partnerki: „Trochę się wstydziła”.

\subsubsection{Transport do kasy}

Badani z University of Dayton określili ten etap jako gorszy od pozostałych, a nawet „ciągnący się w nieskończoność”. Wśród ankietowanych można wyróżnić dwie strategie radzenia sobie $\mathrm{z}$ sytuacją: jak najszybsze udanie się do kasy lub kamuflaż produktu, czyli zastosowanie strategii dodatkowego zakupu. Jedna studentka kupiła nawet przedmioty, które nie były jej potrzebne, a miały służyć podwyższeniu jej poczucia komfortu: „Condoms were the only items on my list to get that day, but I could never go to the register with just a box of condoms. So I also picked up magazines, gum, and candy to cover up the very obvious packaging of the box"17.

Badani z Uniwersytetu Wrocławskiego nie wyróżnili tego etapu. Istnieją dwa powody, które pozwalają to wyjaśnić. Pierwszym z nich jest sama lokalizacja prezerwatyw: „Będąc już przy kasie dorzuciłam do zakupów jeszcze prezerwatywy”, natomiast drugim jest po prostu neutralny stosunek: „Tak jak każdą inną rzecz po prostu zgarnęłam i poszłam do kasy”.

\subsubsection{Wybór kasjera i zakup}

Większość amerykańskich studentów wolała udać się do kasjerki, która była młodą kobietą, niemającą matczynych cech. Część badanych nawet specjalnie czekała, aż kasa $\mathrm{z}$ wybranym sprzedawcą się zwolni. Wybór osoby z takimi cechami był uzasadniany tym, że kobieta najprawdopodobniej nie powie uszczypliwego żartu.

Ten etap wiązał się $\mathrm{z}$ ogromnym stresem, nieokreślonym wprost, jednak wynikającym $\mathrm{z}$ analizy objawów psychosomatycznych. Jedna z badanych porównała sytuację do sytuacji egzaminacyjnej: „I got this sensation throughout my body as if I was just about to take a test. You know, the feeling that overcomes you when you get all nervous inside and don't know what to expect... I told myself to take a deep breath and it'd all be ok"18.

Studenci z drugiego badania nie poświęcali czasu na wybór kasjera lub korzystali $\mathrm{z}$ kasy samoobsługowej.

\footnotetext{
17 Ibidem, s. 8.

18 Ibidem.
} 


\subsubsection{Oczekiwanie na reakcję}

Część osób z pierwotnie badanej grupy oczekiwała na negatywną reakcję lub zgryźliwy komentarz ze strony kasjera. Jeden ze studentów doświadczył nieprzyjemnej sytuacji, słysząc od pracownika sklepu następujące słowa: „I know what you're going to be doing tonight" ${ }^{19}$. Mimo że większość nie spotkała się z żadną reakcją, to i tak czuła wewnętrzną potrzebę usprawiedliwienia się i dobrowolnie przyznawała się kasjerom do tego, że uczestniczy w eksperymencie.

Tylko jeden ze studentów Uniwersytetu Wrocławskiego oczekiwał reakcji ze strony sprzedawcy. Istotny jest tutaj kontekst — zakupu dokonywał na Ukrainie w obecności znajomego: „A nuż sprzedawczyni - Ukrainka, więc pewnie konserwatywna dość osoba - pomyśli sobie, że mam jakieś plany wobec rzeczonego kolegi?”. Jego założenia okazały się błędne, a sam zakup „przebiegł bez problemu”.

O ile respondenci $z$ drugiego badania rzadko spodziewali się i doświadczali jakichkolwiek reakcji ze strony pracowników sklepu, o tyle zdarzyły się przypadki przyciągnięcia uwagi innych. Jedna ze studentek, która zadeklarowała, że zakup nie sprawia jej trudności, była zdziwiona reakcją innych klientów: „Dwie nastolatki, wyglądały na 12-13 lat, które cicho chichotały widząc mnie przed półką z prezerwatywami itp. wywołały raczej rozbawienie, skoro je w takim wieku porusza osoba kupująca prezerwatywy w sklepie to chyba ktoś nie podołał w aspekcie edukacji seksualnej”. Inna badana, dla której zakup również był neutralnym doświadczeniem, wręcz oczekiwała reakcji zewnętrznej widowni: „Lubię obserwować reakcje białych heteronormatywnych mężczyzn w średnim wieku kiedy pewna siebie podążam $\mathrm{z}$ opakowaniem prezerwatyw do kasy". Wypowiedź ta brzmi niemalże prowokacyjnie, jednak uważam, że jest $\mathrm{w}$ dużym stopniu podszyta frustracją i dumą: frustracją wynikającą $\mathrm{z}$ tego, że społeczeństwo nadal uważa kupowanie prezerwatyw za tabu, oraz dumą spowodowaną dojrzałą i jedyną słuszną (wedle autorki) postawą.

\subsubsection{Refleksje}

Odczucia studentów z University of Dayton tuż po zakupie były bardzo zróżnicowane. Wśród nich najczęściej pojawiały się: ulga, duma, wstyd lub zażenowanie. Osoby odczuwające dumę często nazywały siebie „odpowiedzialnymi młodymi dorosłymi”, część z nich była nawet wdzięczna profesorce za takie zadanie, bo robili to pierwszy raz: „And now I feel so much more comfortable with the situation. I really think that the assignment helped me and now if I ever do need to buy condoms in the future the situation will not be as intimidating" 20 .

Część osób, u których sytuacja wywołała wstyd, oświadczyła, że nie zrobi tego ponownie: „Needless to say that this is the absolute last time I ever buy condoms

\footnotetext{
19 Ibidem, s. 9.
}

20 Ibidem, s. 10. 
again. I'll just leave that job for [boyfriend] to do in the future"21. Taką deklarację przedstawiło $8 \%$ kobiet $\mathrm{z}$ całego badania, żaden mężczyzna nie doszedł do podobnych konkluzji.

Refleksje studentów z Uniwersytetu Wrocławskiego były bardziej lakoniczne lub w ogóle nie występowały. Ich wypowiedzi często kończyły się w sposób sugerujący nieistnienie problemu z zakupem. Jedna z badanych podsumowała: „Zakupy jak zakupy", co sugeruje, że proces ten nie wywołał w niej silnych emocji.

Rzeczą, nad którą należy się pochylić, a która nie wybrzmiała wcześniej, są odpowiedzi trolli internetowych. Na niewielką grupę dwudziestu osób aż trzy uznały temat pracy za godny żartu, co nie znaczy, że ich wypowiedzi były mniej diagnostyczne od pozostałych. Jeden ze studentów kreatywnie wykorzystał słowo preservatives (konserwanty), tworząc grę słowną: „I wanted to buy an Orange Juice but it was mentioned it does have preservatives. So I decided to Get rid of this kind of product. I want to be fit". Dwie pozostałe osoby udzieliły bardzo lakonicznych i wulgarnych odpowiedzi. Ich istnienie przede wszystkim zaprzecza temu, że nabycie prezerwatyw jest dla wszystkich „Zwykłym zakupem” - gdyby tak było, to rozmawianie o nich nie sprawiłoby trudności i nikt nie dostrzegłby w tym potencjału humorystycznego.

\section{Podsumowanie badań}

Oba badania potwierdzają, że zakup prezerwatyw może się wiązać z odczuwaniem wstydu. Nie jest to jednak wniosek, który można zgeneralizować na całą populację — próby badawcze są za małe oraz niewystarczająco zróżnicowane. Co więcej, nawet w ich obrębie istnieją jednostki, które nie odczuwały negatywnych emocji związanych z zakupem. Zaskakujące jest jednak to, że w polskim badaniu takie osoby przeważały. Polscy studenci rzadziej odczuwali wstyd, co jest niespodziewanym wynikiem. Wydaje się on zaprzeczać temu, co wiemy z literatury o różnicach międzykulturowych - chociażby jednemu z wymiarów kultury, który zaprezentował Gert Hofstede.

Wymiar unikania niepewności przedstawia sposób, w jaki jednostki radzą sobie w sytuacjach nowych, nieznanych lub niepewnych. Kultury o wysokim wskaźniku UAI (ang. Uncertainty Avoidance) charakteryzują się wysokim poziomem stresu, silnym niepokojem oraz osiągają wysokie wyniki na skali neurotyzmu. Neurotyzm zaś jest skorelowany z inną istotną cechą — wstydliwością. Polska należy do kultur mających jeden z najwyższych wskaźników unikania niepewności, natomiast USA odnotowuje jeden $\mathrm{z}$ niższych wyników ${ }^{22}$. W związku z tym byłam przekonana, że studenci

21 Ibidem, s. 9.

22 M.Czerwonka, Charakterystyka wskaźników modelu kulturowego Hofstede, [w:] O nowy ład finansowy w Polsce. Rekomendacje dla animatorów życia gospodarczego, red. J. Ostaszewski, Warszawa 2015, s. $288-289$. 
Uniwersytetu Wrocławskiego będą bardziej przeżywać zakup, jednak badanie tego nie wykazało. Co więc mogło wpłynąć na taki wynik?

Pierwszym powodem jest różnica w liczbie badanych osób (prawie sześciokrotna). Z uwagi na to porównywanie wniosków obu badań wydaje się błędne. Drugą przyczyną może być jedenastoletnia przerwa między badaniami. Oczywiste jest, że realia 2020 roku różnią się znacznie od tych z 2009 roku. Tematy dotyczące sfery intymnej są coraz częściej poruszane w sferze publicznej, przestają być uznawane za coś, czego należy się wstydzić. Gdyby amerykańskie badanie odbyło się w 2020 roku, prawdopodobnie przebadani studenci byliby mniej wstydliwi - jest to jednak tylko moje założenie niepotwierdzone faktami.

\section{Wnioski}

Narracji dotyczących procesu kupowania prezerwatyw jest zapewne tak wiele jak osób go doświadczających. Nie można jednak zignorować tego, że dla sporej części konsumentów jest to wciąż nieprzyjemny proces, wywołujący często negatywne emocje. Warto więc się zastanowić, jakie skutki przynosi doświadczanie tych negatywnych emocji.

Tak prozaiczna czynność jak zakup prezerwatyw może mieć duży wpływ na zdrowie, szczególnie gdy rozważymy najczęstszą metodę radzenia sobie z emocjami jej towarzyszącymi, czyli rezygnację z zakupu. Mimo stosunkowo łatwego dostępu do antykoncepcji liczba niechcianych ciąż i chorób przenoszonych drogą płciową wciąż wzrasta. Według Światowej Organizacji Zdrowia statystyki dotyczące zakażeń chorobami przenoszonymi drogą płciowa wyglądają następująco: $340 \mathrm{mln}$ nowych zachorowań rocznie (wzrost o 50\% od 1990 roku), w tym ponad 50\% chorych przed 25 . rokiem życia. Zgodnie z danymi WHO aż $41 \%$ osób ze wspomnianej grupy wiekowej uprawia niezabezpieczony seks ${ }^{23}$.

Niechęć do zakupu prezerwatyw może nie byłaby tak duża, gdyby ludzie byli świadomi istoty i skali problemu. W Polsce niestety jest to rzeczywistość życzeniowa. W związku z groteskowymi lekcjami WDŻ i walką z edukatorami seksualnymi uzyskanie przez adolescenta rzetelnej wiedzy na temat seksu wydaje się niemożliwe. Według badań przeprowadzonych przez Warszawski Uniwersytet Medyczny wśród uczniów klas maturalnych ich wiedza jest jednoznacznie niewystarczająca ${ }^{24}$.

Młodzi ludzie są szczególnie narażeni na zakażenie chorobami przenoszonymi drogą płciową lub ciąże. Poza brakiem fundamentalnej wiedzy statystycznie są oni

23 G. Jarząbek-Bielecka et al., Choroby przenoszone drogą płciową u nastolatków, „Current Gynecologic Oncology" 2015, nr 13, s. 20-26.

${ }^{24}$ D. Olejniczak, U. Religioni, K. Wodzyńska, Wiedza uczniów klas maturalnych na temat chorób przenoszonych droga ptciowa, „Problemy Pielęgniarstwa” 2012, nr 20, s. 317-326. 
bardziej zawstydzeni przy zakupie prezerwatyw niż osoby starsze. Co więcej, przekłada się to bezpośrednio na mniejszą częstotliwość zakupów ${ }^{25}$.

Warto również się zastanowić nad szerszym kontekstem. Skoro zakup prezerwatyw jest powodem do wstydu, z racji bycia swoistą deklaracją stosunku, to czy problem nie tkwi w samym postrzeganiu seksu? Jest on tabuizowany niemal od zawsze i mimo postępującego dyskursu w niektórych środowiskach wciąż nie dochodzi do rozmów na jego temat. Seksualność człowieka jest jego integralną częścią, więc unikanie lub wypieranie jej nie może skutkować niczym pozytywnym.

Jedno jest pewne - o sprawach istotnych należy rozmawiać, nawet jeśli sprawia to ogromne trudności. Dotyczy to zarówno konsumentów, jak i naukowców, szczególnie gdy gołym okiem można dostrzec lukę w wiedzy społeczeństwa. W Polsce jeszcze nikt nie podjął się zbadania kwestii związanej z zakupem prezerwatyw, mimo że jest ona tematem licznych publikacji za granicą. Mogę zatem jedynie liczyć, że w przyszłości problemy konsumentów będą częstszym przedmiotem dyskusji, co przyczyni się do znalezienia ich rozwiązań.

\section{Bibliografia}

Chudziński W., Pacjent w objęciach psychologii, https://mgr.farm/opinie/pacjent-w-objeciach-psychologii/ (dostęp: 14.05.2020).

Czerwonka M., Charakterystyka wskaźników modelu kulturowego Hofstede, [w:] O nowy ład finansowy w Polsce. Rekomendacje dla animatorów życia gospodarczego, red. J. Ostaszewski, Warszawa 2015, s. 281-292.

Dahl D., Gorn G., Weinberg C., The impact of embarrassment on condom purchase behaviour, „Canadian Journal of Public Health" 1998, 89, s. 368-390.

Grupa Edukatorów Seksualnych Ponton, Skąd wiesz? Jak wyglada edukacja seksualna $w$ polskich domach, http://ponton.org.pl/wp-content/uploads/2018/09/Sk\%C4\%85d-wiesz-RAPORT_ostateczny. pdf (dostęp: 14.05.2020).

Heflick N., The spotlight effect. Do as many people notice us as we think?, https://www.psychologytoday. com/intl/blog/the-big-questions/201111/the-spotlight-effect (dostęp: 14.05.2020).

Jarząbek-Bielecka K., Kędzia W., Mizgier M., Pawlaczyk M., Pisarska-Krawczyk M., Choroby przenoszone droga ptciową u nastolatków, „Current Gynecologic Oncology” 2015, nr 13, s. 20-26.

Joos K., Picca L.H., The great condom adventure: Analyzing college students' narratives of buying condoms, „Sociology, Anthropology, and Social Work Faculty Publications”, 8, 2009, s. 4-5.

Konecki K., Socjologia emocji wedtug Thomasa Schefa, [w:] Emocje w życiu codziennym. Analiza kulturowych, społecznych i organizacyjnych uwarunkowań ujawniania i kierowania emocjami, red. K. Konecki, B. Pawłowska, Łódź 2014.

Kotarska J., Nie zrobię tego z żona, https://www.psychologiaprzykawie.pl/blog/nie-zrobie-tego-z-zona (dostęp: 14.05.2020).

Li Y.T., Yang D.F., Zhou H., A literature review of consumption embarrassment and prospects, „American Journal of Industrial and Business Management" 8, 2018, s. 686-699.

25 D. Dahl, G. Gorn, C. Weinberg, The impact of embarrassment on condom purchase behaviour, „Canadian Journal of Public Health" 89, 1998, nr 6, s. 368-390. 
Młynarska-Jurczuk A., Wstyd jako emocja ucieleśniona - twarz, ciało i role płciowe w procesie społecznej konstrukcji wstydu, „Dyskursy Młodych Andragogów” 2016, nr 17.

Olejniczak D., Religioni U., Wodzyńska K., Wiedza uczniów klas maturalnych na temat chorób przenoszonych droga płciową, „Problemy Pielęgniarstwa” 2012, nr 20, s. 317-326.

Wojciszke B., Psychologia społeczna, Warszawa 2011.

\section{Consumer experiences of purchasing condoms - the analysis of emotions and customers' journey}

\section{Summary}

Unprotected sex carries a number of consequences, but according to a WHO report, as many as $41 \%$ of people under the age of 25 engage in such risky behaviour. The reasons for this can be traced to insufficient sex education, lack of knowledge about the risks, or limited access to contraception. Less obvious causes are the negative emotions that customers can experience when buying condoms. The article aims to present the experience of purchasing this product, as well as to verify to what extent these negative emotions affect the resignation from subsequent purchases. I will portray the customer journey based on the narrative of students from two universities, consisting of the following stages: preplanning, entering the store, searching for and selecting the product, carrying to the checkout, selecting a cashier and buying, anticipating reactions and reflections.

Keywords: contraception, condom purchase, customer journey, shame, consumer behavior 